\title{
BMC Research Notes
}

\section{Characterization of culturable bacterial communities associated with cage cultured fish under different stocking densities in Setiu Wetlands, Terengganu, Malaysia.

\author{
--Manuscript Draft--
}

Manuscript Number:

Full Title:

Article Type:

Funding Information:

Abstract:

Corresponding Author:

Corresponding Author E-Mail:

Corresponding Author Secondary

Information:

Corresponding Author's Institution:

Corresponding Author's Secondary Institution:

First Author:

Mohammed Salah M.Tawfeeq, MSc in Tropical Biodiversity and Ecosystems

First Author Secondary Information:

Order of Authors:

Mohammed Salah M.Tawfeeq, MSc in Tropical Biodiversity and Ecosystems

Mohd Effendy Abd. Wahid, Ph.D in Veterinary Immunopathology

Musa Najiah, PhD in Microbiology

Isabelle George, $\mathrm{PhD}$ in Bioengineering

Order of Authors Secondary Information:

Opposed Reviewers:

Additional Information:

Question

\section{Response}

Has this manuscript been submitted before to this journal or another journal in the $<a$

href="https://www.biomedcentral.com/p/th e-bmc-series-journals\#journallist"

target="_blank" >BMC series $<$ / a ? 


\title{
Characterization of culturable bacterial communities associated with cage cultured fish under different stocking densities in Setiu Wetlands, Terengganu, Malaysia
}

\author{
Authors: \\ * Mohammed M. Tawfeeq \\ Faculty of Science, Department of Organism Biology, Université Libre de Bruxelles, \\ 1050, Brussels, Belgium. \\ muhamed.bio89@gmail.com \\ - Mohd Effendy Abd.Wahid \\ Faculty of Fisheries and Food Science, Universiti Malaysia Terengganu, Malaysia. \\ effendy@umt.edu.my \\ - Musa Najiah \\ Faculty of Fisheries and Food Science, Universiti Malaysia Terengganu, Malaysia. \\ najiah@umt.edu.my \\ - Isabelle George \\ Laboratoired'Ecologie des Systemes Aquatiques, Université Libre de Bruxelles, \\ Belgium. \\ igeorge@ulb.ac.be \\ * Corresponding author \\ muhamed.bio89@gmail.com
}




\section{Abstract}

Objective: The study objective was to evaluate the effects of fish stocking density on the prevalence of pathogens isolated from sixty clinically healthy fishes reared under different densities in floating net-cages in Setiu lagoon, Terengganu state, Malaysia. Results: The water temperature, $\mathrm{pH}$, dissolved oxygen, total dissolved solids, salinity, water clarity, depth, and coliform concentration, were all determined within the fish cages. The healthy fish samples were randomly collected from 3 sites $(A, B$, and $C)$ in cages with low and high stocking densities at each site. The bacteria were isolated from the skin, gills, kidneys, and liver of each fish sample, followed by identification to species level using the VITEK-2 system. Water quality parameters showed no differences between the cages of low and high fish densities except for site $\mathrm{C}$. The total number of isolates, microbial species, and the number of pathogens isolated from fish revealed no significant difference between the fish stocked in low and high densities. A total of 25 bacterial species were isolated, which included 14 grampositive and 11 gram-negative.

Keywords: Cage aquaculture, fish stocking density, pathogens, water quality, coliforms. 


\section{Introduction}

Nowadays, the demand for food is increasing especially for fish consumption. Therefore, solutions have been introduced mainly by intensive aquaculture systems that have become the point of economic interest of many farmers. In Setiu Wetlands, Malaysia, this area has a significant potential for both aquaculture activities and fisheries such as floating net cages that have become one of the fastest flourishing economic activities. Stocking large quantities of biomass/fish numbers with larger feed inputs in the fish ponds allows more financial income, but it can eventually lead to disease outbreaks [7], [8]. Other studies have indicated that intensive stocking fish densities in cage cultures increase the competition for food, living space, and social interactions between the fish individuals (aggressive behaviors) [23]. Moreover, it causes lowering of individual fish growth and increasing cortisol (stress hormone) levels $[25,27]$. In addition, fish compression at the bed of the cage culture due to gravitational fish weight, which can cause abrasions and injuries by spines of the adjacent fish [6].

The intensive production of fish in cages might induce deleterious effects on the ambient aquatic environment such as water pollution resulting from excess of uneaten fish feed and fish excreta from cages to the surrounding environment. makes the cage farms as an extra source of nutrients that encourage microbial growth. thus, poor water quality is considered a source of stress that reduces the health of cultured fish and makes them more susceptible to bacterial infections [29].

This study was undertaken to evaluate the effects of fish stocking density reared in commercial cage cultures associated with prevalence of pathogens and its water quality parameters. 


\section{Main text}

\section{Materials \& Methods}

\section{Study area}

The study was conducted at a private commercial fish farm located in Setiu Wetland, along the north coast of the Terengganu state, Malaysia (Additional Figure S1 (A) \& (B)).

\section{Culture cages}

The fish farm has a total of 50 floating net-cages filled with the tiger grouper (Epinephelus fuscoguttatus) and the Asian seabass (Lates calcarifer). These cages came in two different depths (1.7 $\mathrm{m}$ in sites $\mathrm{A}$ and $\mathrm{C}$, while $1.9 \mathrm{~m}$ in site $\mathrm{B})$. The fish stocking density was determined by the number of fish per cage of the threedimensional medium [6] (Table 1).

\section{Fish Sampling}

The fish samplings were conducted in July 2018 during the dry season from three sites A, B, and C (Figure S1 ). Sixty fish (700 - $1000 \mathrm{gm})$ were randomly collected from 3 sites (Table 1). According to the farm history, there were no disease outbreaks on this farm. 


\section{Water quality measurements}

Temperature, $\mathrm{pH}$, dissolved oxygen (DO), total dissolved solids (TDS), salinity and water transparency (WT) were determined using multiprobe sensor (YSI, 556 MPS, USA) and Secchi disk (Wildlife Supply Company, USA) within the cages before, during and after the fish sampling; below the water surface, $1 \mathrm{~m}$, and $2 \mathrm{~m}$. The water flow rate and depth of the water column were assessed using a current water meter (Valeport, UK), and ultrasonic depth sensor (Speed Tech SM-5, USA), respectively. Geographic Positioning System (GPS) coordinates were taken using a Garmin GPS (SNAP 276C, US). The study area map was created using: Google Earth V. 7.3 and ArcMap V. 10.3.

\section{Microbial water quality}

Water samples were collected in sterile plastic containers of $50 \mathrm{ml}$ within the fish sampling cages $15-20 \mathrm{~cm}$ below the water surface. The fecal contamination in the water samples was analysed according to the guidelines [3], [12], [17], [28].

\section{Bacterial isolation methods}

The selected fish was observed for any signs of lesions. Necropsy was done according to [18].

The bacteria were isolated in three replicates from the skin, gills, liver and kidneys, plated on Zobell Marine Agar (HIMEDIA, India), Thiosulphate-Citrate Bile Salts Sucrose agar (Difco ${ }^{\mathrm{TM}}$, USA), ready to use Blood Agar plates (Thermo Scientific Microbiology Sdn Bhd, Malaysia) and incubated at $37^{\circ} \mathrm{C}$ for 24 hours according to 
[22]. The purified isolates were identified [5], [7], [9], [15], [21] to species level using an automated bacterial identification instrument (VITEK-2, BioMérieux, USA).

\section{Data analysis}

The data analysis was performed using R software version 3.3.2, packages used were: psych, and stats. The assumptions of parametric analysis were not met. Nonparametric tests were done according to [13], [16].

The Spearman's rank correlation test (rho) was used to determine the correlations between the water quality parameters, fish density and the total number of microbial isolates.

All significant differences were $p<0.001$ (with Bonferroni correction) unless mentioned otherwise.

\section{Results}

\section{Physicochemical parameters}

Mean values of the water parameters with their standard deviations $( \pm S D)$ are presented in Table S1.

All water quality parameters were not significantly different between the cages (A1 and $\mathrm{A} 2$ ), and (B1 and $\mathrm{B} 2$ ), with the exception for the $\mathrm{pH}$ in both $\mathrm{B}$ sites and water flow rate between all sampling sites $(P<0.05)$.

The sites $(C 1$ and $C 2)$ showed a significant difference $(P<0.05)$ in all water parameters except for DO and Secchi depth readings. 


\section{Microbiological parameters}

Total coliform (TCF) counts, fecal coliforms counts and thermotolerant fecal coliforms (FC) are shown in Tables S2, S3, and S4.

\section{Bacterial isolates}

A total of 88 bacterial strains were isolated from 60 visually healthy fish except for one sample that consisted of congested and swollen kidneys upon necropsy,

The number of Alpha-hemolysin ( $\alpha$ ) and Beta-hemolysin $(\beta)$ bacteria was higher than the Gamma strains number $(\mathrm{Y})$.

The number of identified species was 25 , which were $56 \%$ gram-positive bacteria and $44 \%$ gram-negative bacteria. The dominant bacteria were mostly gram-positive (69.32\%) compared to gram-negative ones (28.41\%), (Tables S5, S6) (Figure 2, Figure S2).

\section{Correlation parameters}

Negative strong and significant correlations were observed for: salinity, TDS, Secchi depth and $\mathrm{pH}$ with the total number of bacterial isolates $(\mathrm{P}<0.05)($ Table $\mathrm{S} 7$, Figure S3). Temperature, water flow, TCF, FC concentrations and fish density were non-significant $(P>0.05)$. The DO revealed a non-significant negative moderate 
correlation $(P>0.05)$. Fish density showed a non-significant and moderate positive correlation with the total bacterial counts $(P>0.05)$.

\section{Discussion \& Conclusions}

The Physicochemical parameters results indicated water temperature fluctuations within the sampling sites with the lowest temperature at site B due to the highest freshwater discharge from the estuary towards the cages, which frequently carried the metabolic wastes of the fish away from the cages. This variation was attributed to the time of day of sampling, and on the tide [24].

Site $\mathrm{C} 2$ showed the highest temperature and lowest salinity, TDS, and $\mathrm{pH}$ compared with $\mathrm{C} 1$. This site had the highest fish density with a potentially high presence of fish feed that could lead to a high respiration rate due to the fish metabolic needs linked to the digestion of food, and increase fish excreta plus the effect of low water currents at site $\mathrm{C} 1$ and site $\mathrm{C} 2$. This led to increased temperature and lowered $\mathrm{pH}$, besides the low water flow that was probably insufficient to wash away the metabolic wastes. The excess fish food and faces discharged from aquaculture are a major factor contributing to the increased organic decomposition rate, which is responsible for decreasing $\mathrm{DO}$ and $\mathrm{pH}$ in the water column [23, 24].

Noteworthy, both sites $A 2$ and $C 1$ received the lowest water inflow, A2 showed significantly higher mean $\mathrm{DO}$, salinity, TDS and $\mathrm{pH}(\mathrm{P}<0.05)$, except for the temperature. This could be due to widely buffered condition of site $A$ from the seawater currents during high tide, conversely to site $C$ that was subjected more to freshwater fluxes from the estuary, which was markedly discerned with the decreased salinity, TDS, DO, pH and WT at site C; different oxygen requirement of different fish species. 
A study reported the DO concentration at the same Wetland area was low due to the respiration activities of the fish inside the cage area [24].

The salinity had exceeded the optimal range (15-25) ppt for the grouper at site A [20] and $\mathrm{pH}$ levels were less than the optimal range (7.5 - 8.5) for the seabass [2] at site C2, (Table S1), which means the grouper fish in this study were under salinity stress, and the seabass species at site $\mathrm{C} 2$ exposed to non-optimal $\mathrm{pH}$.

Although the physicochemical water parameters were not different between the cages of low and high fish densities, The salinity, TDS, $\mathrm{pH}$, and WT that were observed to have strong negative associations with the presence of total bacterial isolations in all the sampling sites.

High TCF at site $\mathrm{C} 1$, and the lowest at site $\mathrm{A}$, while FC were also the lowest at site A, which may be due to the direct discharge of wastewater from septic tank, industrial wastewater to the Setiu river and due to the vicinity of $C$ sites from the river mouth. Contrary to A sites that are mostly washed by sea water currents during the high tides.

The low water flow rate and high-water clarity at site A likely facilitated the penetration of solar light into the water column, in addition to the high salinity and $\mathrm{pH}$ during solar exposure were considered as exogenous factors that play an important role in accelerated microbial decay rate [19]. Besides, polluted river water could have brought coliforms from the surrounding residential area to the estuary. Hence, the variation of coliform concentrations at sites $B$ and $C$ are associated with hydrodynamics driven by water flow, salinity changes, and the sedimentation rate of the suspended or dissolved particles. 
The correlation coefficient between fish density and the total number of microbial isolates imply that fish density has no direct effect on the total number of bacterial isolates. A study postulated that $50 \mathrm{fish} / \mathrm{m}^{3}$ is optimum stocking density while 75 to $100 \mathrm{fish} / \mathrm{m}^{3}$ is considered high to Nile tilapia species because within those densities a rise in plasma cortisol concentrations was evident due to social stress between fish individuals as well as the survival rate was reduced by $60 \%$ [4]. Researchers recommended the optimum density should not exceed 35 to $43 \mathrm{fish} / \mathrm{m}^{3}[10]$. This suggests that our selected fish stocking densities were within normal ranges in this study.

Similarly, other studies have reported that physico-chemical parameters showed their importance in influencing the occurrence and the density of bacterial populations [1], [11], [14].

The significant difference in total pathogens isolation (Figure 1) between the sites A1 and A2 with the site $C 2$, is attributed to the differences in the fish species and water quality.

Generally, the salinity, TDS, pH, and WT were strongly negatively correlated with the occurrence of total bacterial isolates while neither the fish density nor the coliform concentrations did show a significant correlation with total bacterial isolates among all sites.

The water characteristics have favored the cultured seabass to harbor more pathogens at sites $B$ and $C$, such pathogens may be also the result of the diseased or carrier fish. A non-optimal $\mathrm{pH}$ level was noticed at site $\mathrm{C} 2$ with a potential of high microbial load surrounding the cages. The non-optimal salinity levels are considered a stressful condition to grouper species [20], which led to some bacterial infections. 
Our findings in the present study indicated that fish density has no effects on the pathogen numbers, species numbers, and overall bacterial isolations. This suggests that the fish stocking densities were within the optimum in this study. In this survey, we isolated several bacterial species from the fish, which may be associated with the nature of the environment and water quality surrounding the cages. However, the environmental variables are far more easily exposed to fluctuations, which makes it necessary for further study to investigate such relationships during the wet season.

\section{Limitations}

- A comprehensive estimation of the health risk of this farm is required by using advanced molecular techniques (e.g., examine the virulence genes of pathogenic isolates) to address the problem of infected fish with no clinical signs.

- In order to have a conclusive decision about the study results, it is necessary to have similar experiments in the wet season. 


\section{List of abbreviations}

DO: Dissolved Oxygen

FC: Thermotolerant fecal coliforms

GPS: Geographic Positioning System

SD: Standard deviation

TCF: Total coliform

TDS: Total Dissolved Solids

WT: Water Transparency

$\alpha$ : Alpha-hemolysin

$\beta$ : Beta-hemolysin

ү: Gamma-hemolysin 


\title{
Ethics declarations
}

\author{
Ethics approval and consent to participate \\ This study was approved by the Ethical Review Committee in Universiti Malaysia \\ Terengganu (written consent).
}

\section{Consent for publication}

Not applicable

\section{Availability of data and materials}

All data generated or analysed during this study are included in this published article [in supplementary files]

\section{Competing interests}

The authors declare that they have no competing interests.

\section{Funding}

This research did not receive any specific grant from funding agencies in the public, commercial, or not-for-profit sectors.

\section{Authors' contributions}

Fieldwork, sample collection, all laboratory work, and data analysis were carried out by Mohammed M.Tawfeeq. Mohd Effendy, Musa Najiah, and Isabelle G. are equally contributed to the manuscript editing, pertinent support, and valuable comments. All authors contributed to the article and approved the submitted version. 


\section{Acknowledgments}

We would like to express our sincere thanks and appreciation to the following people: Che Kamal from Institut Oseanografi dan Sekitaran (INOS) department, for his in-situ measurements of water parameters during fieldwork at Setiu Wetlands;

Hasrulhizat bin Hassin, from the aquatic organism health laboratory, for his generous help in providing the needed lab equipment. 


\section{References}

1. Amal, Mohammad Noor Azmai, Mohd Zamri Saad, Abdullah Siti Zahrah, and Abd Rashid Zulkafli. "Water Quality Influences The Presence of Streptococcus agalactiae in Cage Cultured Red Hybrid Tilapia, Oreochromis niloticus × Oreochromis mossambicus." Aquaculture Research 46, no. 2 (2015): 313-23. https://doi.org/10.1111/are.12180.

2. Anil, M K and Santhosh, B and Jasmine, S and Saleela, K. N. and George, Rani Mary and Kingsly, H. Jose and Unnikrishnan, C and Rao, A Hanumantha and Rao, G Syda. "Growth Performance of The Seabass Lates calcarifer (Blotch) in Sea Cage at Vizhinjam Bay Along the South-West Coast of India". Indian Journal of Fisheries, 57 (4), (2010): pp. 65-69.

3. Bumadian, Mohamed. "Detection and Enumeration of Coliform Bacteria in Drinking Water at Hospital of Benghazi, Libya". Journal of Experimental Biology and Agricultural Sciences, 1(6):436-440., October 2013.

4. Chakraborty, Suman Bhusan, Debasis Mazumdar, and Samir Banerjee. "Determination of Ideal Stocking Density for Cage Culture of Monosex Nile Tilapia (Oreochromis niloticus) in India." Proceedings of the Zoological Society 63, no. 1 (2010): 53-59. https://doi.org/10.1007/s12595010-0007-3.

5. Chow, A. W., Gribble, M. J., \& Bartlett, K. H. (1983). "Characterization of the hemolytic activity of Staphylococcus aureus strains associated with toxic shock syndrome." Journal of clinical microbiology, 17(3), 524-528. https://doi.org/10.1128/jcm.17.3.524-528.1983.

6. Conte, F.S. "Stress and the Welfare of Cultured Fish." Applied Animal Behaviour Science 86, no. 3 (2004): 205-23. https://doi.org/10.1016/j.applanim.2004.02.003.

7. Das, A., B. K. Behera, S. Acharya, P. Paria, H. J. Chakraborty, P. K. Parida, and B. K. Das. "Genetic Diversity and Multiple Antibiotic Resistance Index Study of Bacterial Pathogen, Klebsiella pneumoniae Strains Isolated from Diseased Indian Major Carps." Folia Microbiologica 64, no. 6 (2019): 875-87. https://doi.org/10.1007/s12223-019-00701-7.

8. Duarte, Letícia N., Francisco J. R. C. Coelho, Vanessa Oliveira, Daniel F. R. Cleary, Patrícia Martins, and Newton C. M. Gomes. "Characterization of Bacterioplankton Communities from a Hatchery Recirculating Aquaculture System (RAS) for Juvenile Sole (Solea senegalensis) Production." PLOS ONE 14, no. 1 (2019): 1-16. https://doi.org/10.1371/journal.pone.0211209.

9. Donald Breakwell, Bryan MacDonald, Christopher Woolverton, Kyle Smith, Richard Robison. 2007. "Colony morphology protocol." Available at: (https://www.asmscience.org/content/education/protocol/protocol.3136). (Accessed: 27th May 2018).

10. Farhaduzzaman, A.M, Md Hanif, Suzan Khan, Mahadi Osman, Md Neamul, Hasan Shovon, Md Rahman, and Shahida Ahmed." Perfect Stocking Density Ensures Best Production and Economic Returns in Floating Cage Aquaculture System." Journal of Aquaculture Research and Development 11 (2020): 607. https://doi.org/10.35248/2155-9546.20.10.607.

11. Gorlach-Lira, K., Pacheco, C., Carvalho, L.C.T., MeloJúnior, H.N., Crispim, M.C., "The influence of fish Culture in Floating Net Cages on Microbial Indicators of Water Quality." Brazilian Journal of Biology [online]. (2013): v. 73, n. 3, pp. 457-463. https://doi.org/10.1590/S1519-69842013000300001.

12. Jamie Bartram and Gareth Rees, (2000). "Monitoring Bathing Waters - A Practical Guide to the Design and Implementation of Assessments and Monitoring Programmes", ISBN 0-419-24390 1.Available at: (www.who.int/water_sanitation_health/bathing/monbathwat.pdf). (Accessed: $1^{\text {st }}$ May 2018).

13. Illán, Gonzalo. "Risk Factors Associated with the Presence of Parasitic Diseases in Cultured Tench (Tinca Tinca L.) from the Tormes River (NW Spain)." Journal of Aquaculture \& Marine Biology 2 (2015). https://doi.org/10.15406/jamb.2015.02.00027.

14. Ismail, Nurul Izzatul Aliya, Mohammad Noor Azmai Amal, Shamarina Shohaimi, Mohd Zamri Saad, and Siti Zahrah Abdullah. "Associations of Water Quality and Bacteria Presence in Cage Cultured Red Hybrid Tilapia, Oreochromis niloticus $\times$ O. mossambicus." Aquaculture Reports 4 (2016): 57-65. https://doi.org/10.1016/j.aqrep.2016.06.004.

15. Karen Reiner, (2010). "Catalase test protocol." Available at: (https://www.asmscience.org/content/education/protocol/protocol.3226). (Accessed: 26th July 2018). 
16. Mcknight, Patrick, and Julius Najab. "Mann-Whitney U Test," 2010. https://doi.org/10.1002/9780470479216.corpsy0524.

17. Mishra, Meerambika, Ananta P. Arukha, Amiya K. Patel, Niranjan Behera, Tapan K. Mohanta, and Dhananjay Yadav. "Multi-Drug Resistant Coliform: Water Sanitary Standards and Health Hazards." Frontiers in Pharmacology 9 (2018): 311. https://doi.org/10.3389/fphar.2018.00311.

18. Nagasawa, K. and E. R. Cruz-Lacierda (eds.). "Diseases of Cultured Groupers." Southeast Asian Fisheries Development Center, Aquaculture Department, Iloilo, Philippines. 2004: 81 p.

19. Nelson, Kara L, Alexandria B Boehm, Robert J Davies-Colley, Michael C Dodd, Tamar Kohn, Karl G Linden, Yuanyuan Liu, et al. "Sunlight-Mediated Inactivation of Health-Relevant Microorganisms in Water: A Review of Mechanisms and Modeling Approaches." Environmental Science. Processes \& Impacts 20, no. 8 (2018): 1089-1122. https://doi.org/10.1039/c8em00047f.

20. Noor, N. M., S. K. Das, Z. C. Cob, and M. A. Ghaffar. "Effects of Salinities and Diets on Growth of Juvenile Hybrid Grouper, Epinephelus fuscoguttatus and E. lanceolattus." Turkish Journal of Fisheries and Aquatic Sciences 18 (2018): 1045-51.

21. Pincus, David, (2014). "Microbial Identification Using The Biomerieux VITEK $® 2$ System." J. Encyclopedia of Rapid Microbiological Methods. (2014). 2.

22. Public Health England, (2017). "Inoculation of Culture Media for Bacteriology." UK standards for microbiology investigations (SMI). Q 5 Issue 2. Available at:(https://www.gov.uk/government/publications/smi-q-5-inoculation-of-culture media-for bacteriology). (Accessed: 20th June 2018).

23. Suratman, Suhaimi, A Hussein, Mohd Talib Latif, K Weston, Dan Piawai, Kualiti Kriteria, Marin Air, and Malaysia. "Reassessment of Physico-Chemical Water Quality in Setiu Wetland, Malaysia." Sains Malaysiana 43 (September 1, 2014): 1127-31.

24. Suratman, Suhaimi, A Hussein, Norhayati Mohd Tahir, Mohd Talib Latif, Roslanzairi Mostapa, and K Weston. "Seasonal and Spatial Variability of Selected Surface Water Quality Parameters in Setiu Wetland, Terengganu, Malaysia." Sains Malaysiana 45 (2016): 551-58.

25. Wang, Yanfeng, Liang Chi, Qinghua Liu, Yongshuang Xiao, Daoyuan Ma, Zhizhong Xiao, Shihong Xu, and Jun Li. "Effects of Stocking Density on the Growth and Immunity of Atlantic Salmon Salmo Salar Reared in Recirculating Aquaculture System (RAS)." Journal of Oceanology and Limnology 37, no. 1 (2019): 350-60. https://doi.org/10.1007/s00343-0197350-7.

26. Wang, Yaping, Aoyun Li, Xiong Jiang, Hui Zhang, Khalid Mehmood, Lihong Zhang, Jinhuan Jiang, Muhammad Waqas, Mujahid lqbal, and Jiakui Li. "Probiotic Potential of Leuconostoc pseudomesenteroides and Lactobacillus Strains Isolated from Yaks." Frontiers in Microbiology 9 (2018): 2987. https://doi.org/10.3389/fmicb.2018.02987.

27. Wang, Yi-Wei, Jian Zhu, Xian-ping Ge, Sheng-Ming Sun, Yan-Li Su, Bing Li, Yi-Ran Hou, and Ming-Chun Ren. "Effects of Stocking Density on the Growth Performance, Digestive Enzyme Activities, Antioxidant Resistance, and Intestinal Microflora of Blunt Snout Bream (Megalobrama amblycephala) Juveniles." Aquaculture Research 50, no. 1 (2019): 236-46. https://doi.org/10.1111/are.13889.

28. WHO:Multiple Tube Method for Thermotolerant (Faecal Coliform). Available at: (https://www.who.int/water_sanitation_health/water-quality/small-community management/2edvol3i.pdf?ua=1). (Accessed; 18th June 2018).

29. Zamri-Saad, M., Amal, M.N.A., Siti-Zahrah, A., Zulkafli, A.R., "Control and Prevention of Streptococcosis in Cultured Tilapia in Malaysia: a review." Pertanika J. Trop. Agric Sci. 37:(4), (2014):389-410. 
Table 1. Study sampling design, fish species, and their densities among the sampling sites.

\begin{tabular}{|c|c|c|c|c|c|c|}
\hline Cages & $\begin{array}{c}\text { Total fish } \\
\text { no. } \\
\text { stocked } \\
\text { per net- } \\
\text { cage } \\
\end{array}$ & $\begin{array}{c}\text { Stocking } \\
\text { density } \\
\left(\text { fish } / \mathrm{m}^{3}\right)\end{array}$ & $\begin{array}{l}\text { Sampled } \\
\text { Fish }\end{array}$ & $\begin{array}{c}\text { Fish } \\
\text { species }\end{array}$ & $\begin{array}{l}\text { Sampling } \\
\text { sites }\end{array}$ & $\begin{array}{c}\text { GPS } \\
\text { coordinates }\end{array}$ \\
\hline \multirow{3}{*}{$\begin{array}{l}\text { Low fish } \\
\text { density }\end{array}$} & 300 & 12 & 10 & Grouper & ${ }^{*} \mathrm{~A} 1$ & $\begin{array}{l}\mathrm{N} 05^{\circ} 40^{\prime} 59.6^{\prime \prime} \\
\mathrm{E} 102^{\circ} 42^{\prime} 40.7^{\prime \prime}\end{array}$ \\
\hline & 400 & 14.32 & 10 & Seabass & a B1 & $\begin{array}{l}\text { N 0540'54.5" } \\
\text { E 102'42'42.2" }\end{array}$ \\
\hline & 600 & 24 & 10 & Seabass & ${ }^{*} \mathrm{C} 1$ & $\begin{array}{l}\text { N } 05^{\circ} 40^{\prime} 45.1^{\prime \prime} \\
\text { E } 102^{\circ} 42^{\prime} 50.3^{\prime \prime}\end{array}$ \\
\hline \multirow{3}{*}{$\begin{array}{l}\text { High fish } \\
\text { density }\end{array}$} & 600 & 24 & 10 & Grouper & ${ }^{*} \mathrm{~A} 2$ & $\begin{array}{l}\text { N } 05^{\circ} 40^{\prime} 59.5^{\prime \prime} \\
\text { E } 102^{\circ} 42^{\prime} 40.7^{\prime \prime}\end{array}$ \\
\hline & 1000 & 29.23 & 10 & Seabass & ${ }^{w}$ B2 & $\begin{array}{c}N 5^{\circ} 40^{\prime} 54.5^{\prime \prime} \\
\text { E } 102^{\circ} 42^{\prime} 41.4 "\end{array}$ \\
\hline & 1000 & 32.68 & 10 & Seabass & ${ }^{\mathrm{b}} \mathrm{C} 2$ & $\begin{array}{l}\mathrm{N} 05^{\circ} 40^{\prime} 45.6^{\prime \prime} \\
\text { E 102 } 42^{\circ} 50.0^{\prime \prime}\end{array}$ \\
\hline Total & 3600 & 136.23 & 60 & & & \\
\hline
\end{tabular}

The volume of submerged net-cages in the water: ${ }^{*}=24.99 \mathrm{~m}^{3},{ }^{\mathrm{a}}=27.93,{ }^{b}=30.6 \mathrm{~m}^{3, \mathrm{w}}=34.2 \mathrm{~m}^{3}$. 


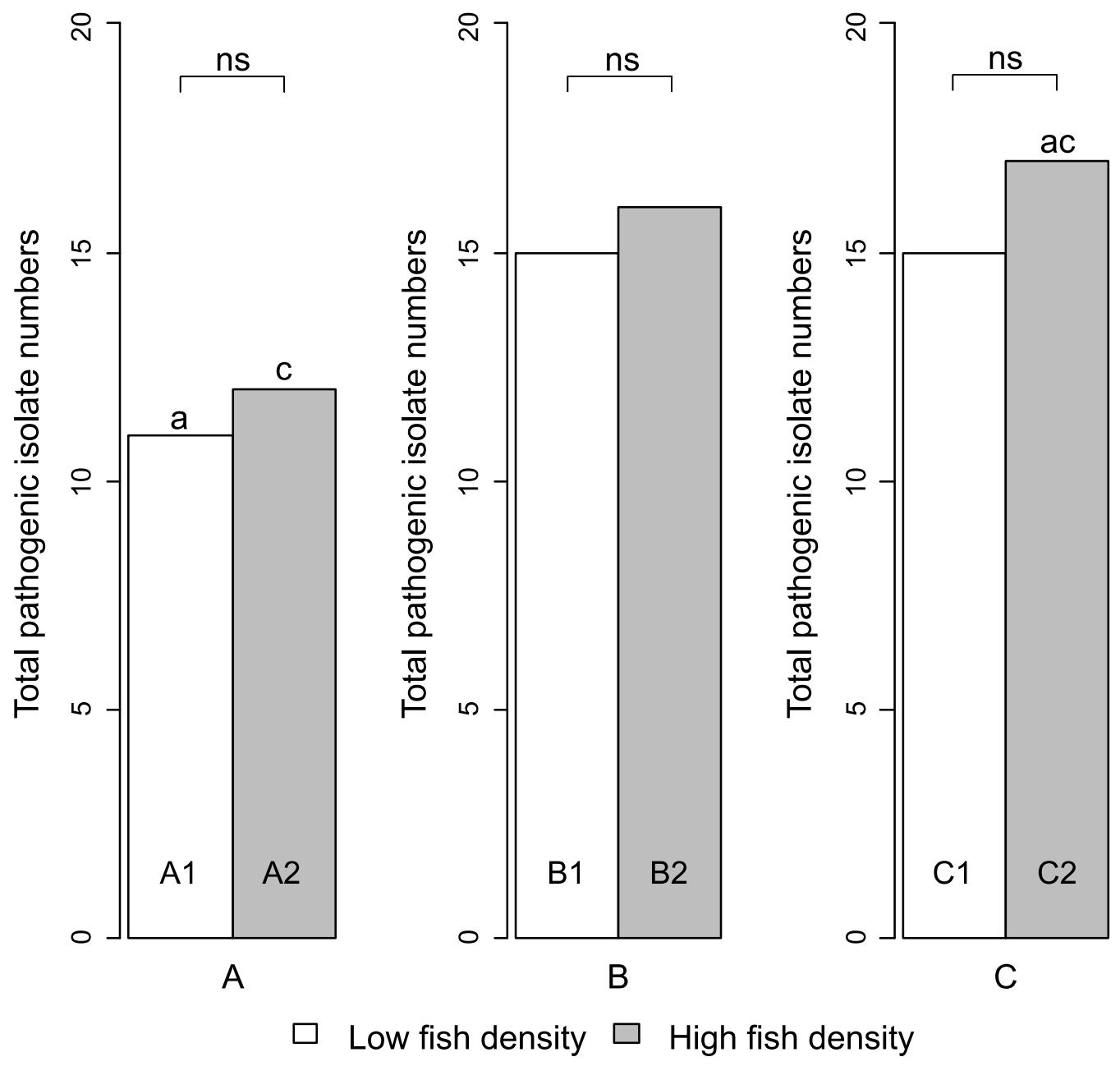

Figure 1. Total numbers of pathogenic bacteria isolated from fish stocked under low and high densities at the different sampling sites. (significance levels: $\mathrm{a}=0.008, \mathrm{c}=0.03, \mathrm{~ns}=$ non-significant). 


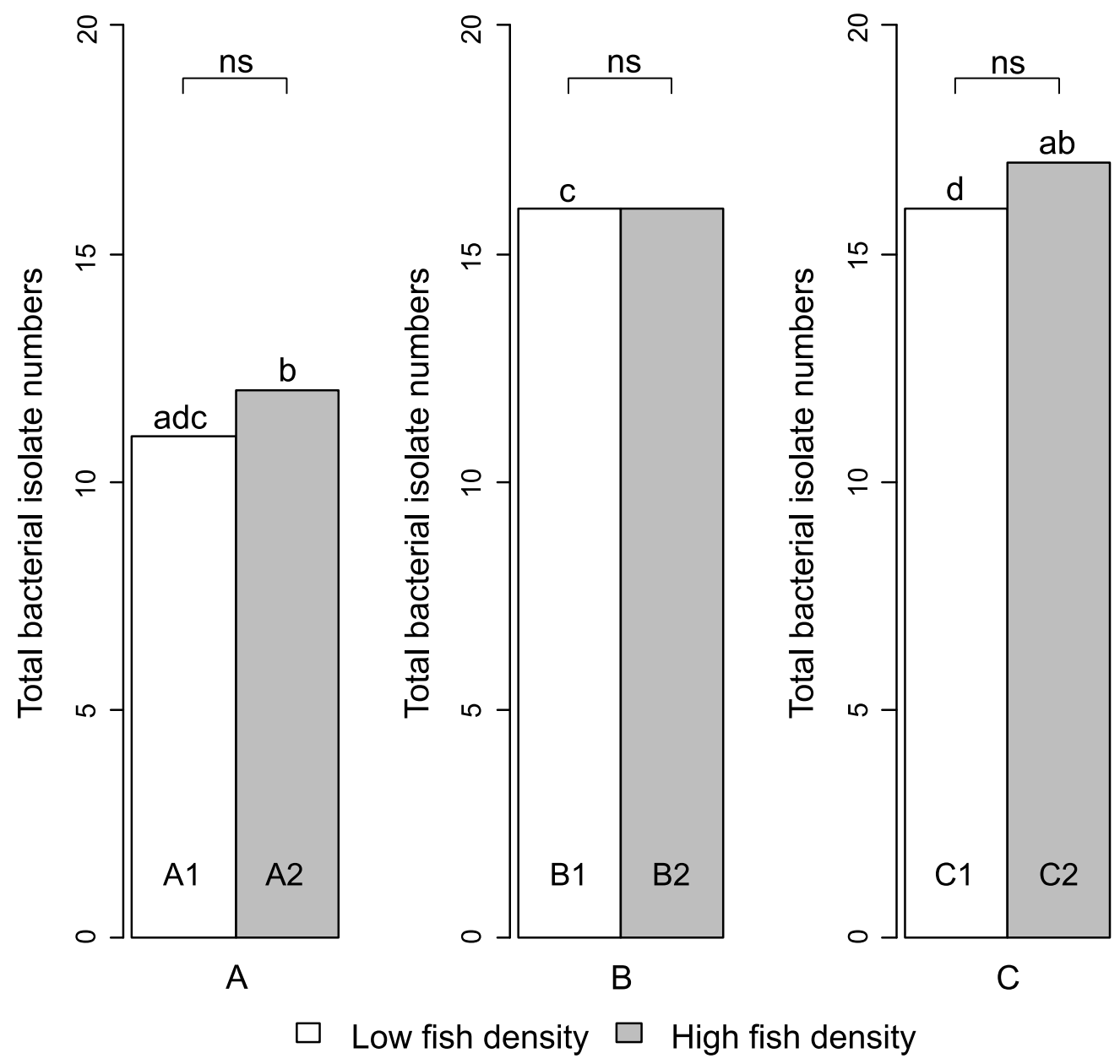

Figure 2. Total numbers of bacteria isolated from fish stocke in high densities at the different sampling sites. (significance levels: a $, c=0.025, b=0.03, d=0.059$, ns $=$ non-significant) 
Figure S1

Click here to access/download

\section{Supplementary Material Figure S1.docx}


Figure S2

Click here to access/download

\section{Supplementary Material Figure S2.docx}


Figure S3

\section{Click here to access/download
Supplementary Material
Figure S3.docx \\ Click here to access/download
Supplementary Material
Figure S3.docx Click here to access/download
Supplementary Material
Figure S3.docx

. .

.


Table S1

Click here to access/download Supplementary Material

Table S1.docx 
Click here to access/download Supplementary Material

Table S2.docx 
Table S3

Click here to access/download Supplementary Material

Table S3.docx 
Click here to access/download Supplementary Material Table S4.docx 
Table S5

Click here to access/download Supplementary Material Table S5.docx 
Table S6

Click here to access/download Supplementary Material

Table S6.docx 
Click here to access/download Supplementary Material Table S7.docx 